\title{
Efficacy and safety of evogliptin in the treatment of type 2 diabetes mellitus in a Brazilian population: a randomized bridging study
}

Cintia Cercato ${ }^{*}$, Joao Soares Felício ${ }^{2}$, Luis Augusto Tavares Russo ${ }^{3}$, Joao Lindolfo Cunha Borges ${ }^{4}$, Joao Salles ${ }^{5}$, Patricia Muskat ${ }^{6}$, Teresa Bonansea ${ }^{7}$, Antonio Roberto Chacra ${ }^{8}$, Freddy Goldberg Eliaschewitz ${ }^{9}$ and Adriana Costa Forti ${ }^{10}$

\begin{abstract}
Background: Evogliptin (EVO) is a potent and selective dipeptidyl peptidase-4 inhibitor (DPP4i) developed for the treatment of type 2 diabetes mellitus (T2DM). DPP4is are known to exhibit a better glucose-lowering effect in Asians compared to other ethnic groups. Once EVO's clinical development program was conducted in Asian patients, this bridging study was designed to validate for the Brazilian population the efficacy and safety of the approved dose regimen (once-daily $5.0 \mathrm{mg}$ ).

Methods: In this randomized, double-blind, double-dummy, parallel trial, 146 patients with T2DM with inadequate glycemic control on diet and exercise $(7.5 \% \leq \mathrm{HbA} 1 \mathrm{c} \leq 10.5 \%)$ were randomly assigned to a 12-week once-daily treatment with EVO $2.5 \mathrm{mg}(\mathrm{N}=35)$, EVO $5 \mathrm{mg}(\mathrm{N}=36)$, EVO $10 \mathrm{mg}(\mathrm{N}=36)$, or sitagliptin (SITA) $100 \mathrm{mg}(\mathrm{N}=39)$. Absolute changes (Week 12-baseline) in $\mathrm{HbA1C}$, fasting plasma glucose (FPG) and body weight (BW) were obtained. One-sided one sample t test was used to determine if mean $\mathrm{HbA} 1 \mathrm{c}$ reduction in each group was $<-0.5 \%$ (beneficial metabolic response). An analysis of covariance estimated the change in $\mathrm{HbA} 1 \mathrm{c}$ and FPG adjusted by baseline $\mathrm{HbA1c}$, FPG, body mass index (BMI) and study site. Response rates to treatment were also established. No between-group statistical comparisons were planned.

Results: $\mathrm{HbA} 1 \mathrm{C}$ mean reductions were $-1.26 \%(90 \% \mathrm{Cl}-1.7 \%,-0.8 \%),-1.12 \%(90 \% \mathrm{Cl}-1.4 \%,-0.8 \%),-1.29 \%$ $(90 \% \mathrm{Cl}-1.6 \%,-1.0 \%)$, and $-1.15 \%(90 \% \mathrm{Cl}-1.5 \%,-0.8 \%)$ in groups EVO $2.5 \mathrm{mg}$, EVO $5 \mathrm{mg}$, EVO $10 \mathrm{mg}$, and SITA $100 \mathrm{mg}$, respectively. FPG levels showed a mean increase of $10.89 \mathrm{mg} / \mathrm{dL}$ in group EVO $2.5 \mathrm{mg}$, with significant mean reductions of $-18.94 \mathrm{mg} / \mathrm{dL},-21.17 \mathrm{mg} / \mathrm{dL}$, and $-39.90 \mathrm{mg} / \mathrm{dL}$ in those treated with EVO $5 \mathrm{mg}$, EVO $10 \mathrm{mg}$, and SITA $100 \mathrm{mg}$, respectively. BW showed significant reductions of approximately $1 \mathrm{~kg}$ in patients treated with EVO $5 \mathrm{mg}$, EVO $10 \mathrm{mg}$, and SITA $100 \mathrm{mg}$. Mean adjusted reductions of HbA1c and FPG levels confirmed the significant clinical benefit of all study treatments. The clinical benefit of EVO's "target" dose $(5 \mathrm{mg})$ was confirmed. No safety concerns were identified.
\end{abstract}

\footnotetext{
*Correspondence: ccercato@netpoint.com.br

${ }^{1}$ Laboratório de Lípides (LIM 10) do Hospital das Clínicas (HCFMUSP) da

Faculdade de Medicina da Universidade de São Paulo, São Paulo, Brasil,

155 Dr Enéas de Carvalho de Aguiar ave., São Paulo, SP 05403-000, Brazil

Full list of author information is available at the end of the article
}

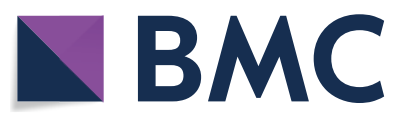

(c) The Author(s) 2019. This article is licensed under a Creative Commons Attribution 4.0 International License, which permits use, sharing, adaptation, distribution and reproduction in any medium or format, as long as you give appropriate credit to the original author(s) and the source, provide a link to the Creative Commons licence, and indicate if changes were made. The images or other third party material in this article are included in the article's Creative Commons licence, unless indicated otherwise in a credit line to the material. If material is not included in the article's Creative Commons licence and your intended use is not permitted by statutory regulation or exceeds the permitted use, you will need to obtain permission directly from the copyright holder. To view a copy of this licence, visit http://creativeco mmons.org/licenses/by/4.0/. The Creative Commons Public Domain Dedication waiver (http://creativecommons.org/publicdomain/ zero/1.0/) applies to the data made available in this article, unless otherwise stated in a credit line to the data. 
Conclusions: These results validate for the Brazilian population the approved dose regimen of EVO (once-daily $5 \mathrm{mg}$ ).

Trial registration ClinicalTrials.gov Identifier: NCT02689362 (first posted on 02/23/2016).

Keywords: Evogliptin, Dipeptidyl peptidase-4 inhibitor, Type 2 diabetes treatment, Bridging study

\section{Background}

DPP4is are oral antidiabetic agents that inhibit the degradation of incretin hormones, such as glucagon-like peptide (GLP-1) and gastric inhibitory polypeptide (GIP), which are secreted in the in response to food ingestion and promote postprandial insulin secretion $[1,2]$. In patients with T2DM, DPP4is reduce the degradation incretin hormones, hence increasing their half-life and promoting their actions (insulin secretion, decrease of gastric emptying rate, and inhibition of glucagon secretion). This class of antidiabetic agents is widely used due to their ease of administration, modest effects on HbA1c, and lack of serious side effects [3].

EVO (DA-1229) is a potent and selective DPP4i developed for the treatment of T2DM [4]. Phase 1 results showed a pharmacokinetic profile that warrants a oncedaily dose regimen, with excellent safety profile $[5,6]$. Pharmacodynamic evaluations showed that EVO promotes $\geq 80 \%$ selective DPP4 inhibition after administration of single $\geq 5 \mathrm{mg}$ doses, with $\geq 80 \%$ of the inhibition maintained for more than $36 \mathrm{~h}$ in steady state. Moreover, postprandial plasma active GLP-1 concentrations were significantly higher in evogliptin-treated subjects compared to those treated with placebo [6]. In a phase 2 dose-finding study, the treatment of patients with T2DM with EVO $5 \mathrm{mg}$ in monotherapy showed the greatest reduction in HbA1c, comparable those achieved with other approved DPP4is [7].

One multicenter, randomized, double-blind, controlled, phase 3 trial confirmed the efficacy and safety of a oncedaily EVO $5 \mathrm{mg}$ monotherapy versus placebo in patients with T2DM inadequately controlled by diet and exercise [8]. Another phase 3 trial determined the non-inferiority and safety of EVO $5 \mathrm{mg}$ compared to sitagliptin in patients with T2DM with inadequate glycemic control under metformin monotherapy (combined therapy) [9]. The results of both pivotal studies supported the regulatory approval of EVO in South Korea. ${ }^{1}$

DPP4is are known to exhibit a better glucose-lowering effect in Asians compared to other ethnic groups due to differences in the pathophysiology of T2DM by ethnic group, with predominance of insulin secretory defect resulting from greater $\beta$-cell deficiency in Asians [10-12].

${ }^{1}$ Suganon $^{\circledR}$-Dong-A ST.
Nonetheless, the approved DPP4is proved to be effective and are used in the same dosages in Asiatic and non-Asiatic countries $[12,13]$.

EVO's clinical development program was conducted in South Korea and enrolled Asian patients. This bridging study was therefore designed aiming at validating the efficacy and safety of the data obtained in these studies, which were conducted in Asian population. The confirmation of the clinical benefit of the approved dose regimen (once-daily EVO $5 \mathrm{mg}$ ) for the Brazilian population allows the validation of all clinical data obtained previously in Asia. This strategy is in accordance with the International Conference of Harmonisation (ICH) guideline on the acceptability of foreign clinical data for medicines from a well-known drug class which are sensitive to ethnic factors [14].

\section{Methods}

This multicentric, randomized, double-dummy, parallel study was conducted in 10 Brazilian sites from August 2017 to May 2018, and enrolled patients with T2DM with inadequate glycemic control on diet and exercise (Clinicaltrials.gov: NCT02689362). Patients aged 20 to 75 years, with $7.5 \% \leq \mathrm{HbA} 1 \mathrm{c} \leq 10.5 \%$ at screening, a body mass index (BMI) between $20 \mathrm{~kg} / \mathrm{m}^{2}$ and $40 \mathrm{~kg} / \mathrm{m}^{2}$ (limits included), and who had not been on any hypoglycemic agent within 12 weeks prior to screening were considered eligible for the study. Subjects with FPG $\geq 300 \mathrm{mg} /$ $\mathrm{dL}$ at screening in the presence of severe signs and/or symptoms of T2DM were excluded. Patients were also excluded in the presence of one or more of the following criteria: New York Heart Association class III or IV congestive heart failure; symptoms of liver and/or gallbladder disease; myocardial infarction, coronary artery bypass surgery, or stroke within 6 months prior to the study screening; history of gastrointestinal tract resection; creatinine clearance (Cockroft-Gault equation) $<60 \mathrm{~mL} /$ min; alanine aminotransferase (ALT) and/or aspartate aminotransferase $(\mathrm{AST}) \geq 2.5$ times the upper limit of normal (ULN); plasma creatine phosphokinase (CPK) $\geq 3$ times the ULN; plasma triglycerides $>400 \mathrm{mg} / \mathrm{dL}$; history of significant skin allergy; use of steroids within 3 months prior to screening; use of warfarin, dicumarinic agents, or digoxin; use of CYP3A4 inducers or inhibitors; untreated or decompensated thyroid disease; history of illegal drug 
or alcohol abuse in the 2 months prior to screening. Pregnant and lactating women were also excluded.

Eligible patients were randomly assigned to a 12-week once-daily treatment with EVO $2.5 \mathrm{mg}$, EVO $5 \mathrm{mg}$, EVO $10 \mathrm{mg}$ or SITA $100 \mathrm{mg}$. All patients were instructed to follow a diet and exercise program during the entire study. HbA1c, FPG and BW were obtained every 4 weeks. The study was approved by the Ethics Committee of each study site, and all patients provided a written informed consent prior to entering the study, which was conducted in compliance with the ethical principles of the Declaration of Helsinki.

The primary endpoint was the change in HbA1c (\%) from baseline (screening) to Week 12. Other efficacy endpoints included change from baseline in FPG (mg/ $\mathrm{dL}$ ) and body weight (BW), as well as the response rate (HbA1c $<7.0 \%$ or $\mathrm{HbA} 1 \mathrm{c}<6.5 \%$ ) at the end of the study treatment (Week 12). Safety was evaluated by means of adverse events (AEs) reporting and vital signs, physical exam findings, electrocardiogram (EKG), and laboratory tests (hematology, chemistry and urinalysis).

Sample size was estimated to identify a clinically relevant $\mathrm{HbA1c}$ mean reduction $(\geq 0.5 \%)$ within each treatment group, considering a one-sided one sample t test, a standard deviation (SD) of $0.68 \%$, a significance level of $5 \%$, and a dropout rate of $15 \%$. Changes from baseline to Week 12 (mean; 90\% CI) in HbA1c and FPG levels, and BW were calculated. Treatment effects on HbA1c and FPG levels adjusted by baseline HbA1c, FPG, BMI and study site were also estimated.

No between-groups comparisons were neither planned nor performed. Descriptive analyses based on bilateral $90 \%$ confidence interval $(90 \% \mathrm{CI})$ were established for each group in order to verify the potential clinical benefit of each individual treatment, aiming to validate the previously approved dosage (once-daily $5 \mathrm{mg}$ ) and safety of EVO for the Brazilian population. Absolute changes from baseline to Week 12 in HbA1c, FPG and BW were obtained (mean; bilateral 90\% CI). One-sided one sample $\mathrm{t}$ test was used to determine if the mean $\mathrm{HbA1c}$ reduction in each treatment group was $<-0.5 \%$ (meaning a beneficial metabolic response to treatment). An analysis of covariance was performed to estimate the change (Week 12-baseline) in HbA1c and FPG (dependent variables) adjusted by baseline HbA1c, FPG, BMI and study site (independent variables). The response rate was established as the proportion of subjects within each group with $\mathrm{HbA} 1 \mathrm{c}<7.0 \%$ or HbA1c $<6.5 \%$ on Week 12 . Efficacy analyses were performed for the intention-to-treat (ITT; primary efficacy analysis) and per protocol (PP) populations.

The incidence of AEs was established for each treatment group. The frequency of clinically relevant (as per the investigator assessment) laboratory tests and EKG changes, as well as vital signs throughout the study were summarized by treatment group. The safety population was used in these analyses.

\section{Results}

Of the 226 patients screened, 146 were randomized and received the treatment for which they were allocated (EVO $2.5 \mathrm{mg}: \mathrm{N}=35$; EVO $5 \mathrm{mg}$ : $\mathrm{N}=36$; EVO $10 \mathrm{mg}$ : $\mathrm{N}=36$; SITA $100 \mathrm{mg}: \mathrm{N}=39$ ). From the 146 randomized subjects, $126(86.3 \%)$ completed the study. The reasons for study discontinuation and the disposition of participants in the study groups and populations are presented in Fig. 1.

Demographics and baseline clinical characteristics were mostly similar among study groups (Table 1 ). The exposure to study treatment was also similar in the four treatment groups.

For the ITT population, HbA1c mean reduction (Week 12 -baseline) was $-1.26 \%(90 \%$ CI $-1.7 \%,-0.8 \%)$, $-1.12 \%$ (90\% CI $-1.4 \%,-0.8 \%),-1.29 \%(90 \% \mathrm{CI}$ $-1.6 \%,-1.0 \%)$, and $-1.15 \%(90 \% \mathrm{CI}-1.5 \%,-0.8 \%)$ in groups EVO $2.5 \mathrm{mg}$, EVO $5 \mathrm{mg}$, EVO $10 \mathrm{mg}$, and SITA $100 \mathrm{mg}$, respectively. It is noteworthy to observe that besides being statistically significant, the upper limit of the $90 \% \mathrm{CI}$ in all study groups was $<-0.5 \%$, the prespecified limit of clinical significance. Median HbA1c changes were $-0.9 \%,-1.1 \%,-1.3 \%$ e $-1.4 \%$ in the groups EVO $2.5 \mathrm{mg}$, EVO $5 \mathrm{mg}$, EVO $10 \mathrm{mg}$, and SITA $100 \mathrm{mg}$, respectively. FPG levels showed a mean increase of $10.89 \mathrm{mg} / \mathrm{dL}(90 \% \mathrm{CI}-5.3 \mathrm{mg} / \mathrm{dL}, 27.1 \mathrm{mg} / \mathrm{dL})$ in subjects treated with EVO $2.5 \mathrm{mg}$, whereas significant reductions of $-18.94 \mathrm{mg} / \mathrm{dL}(90 \% \mathrm{CI}-31.8 \mathrm{mg} / \mathrm{dL},-6.1 \mathrm{mg} /$ $\mathrm{dL}),-21.17 \mathrm{mg} / \mathrm{dL}(90 \% \mathrm{CI}-34.2 \mathrm{mg} / \mathrm{dL},-8.2 \mathrm{mg} / \mathrm{dL})$, and $-39.90 \mathrm{mg} / \mathrm{dL}(90 \% \mathrm{CI}-55.1 \mathrm{mg} / \mathrm{dL},-24.7 \mathrm{mg} /$ $\mathrm{dL}$ ) were observed in those treated with EVO $5 \mathrm{mg}$, EVO $10 \mathrm{mg}$, and SITA $100 \mathrm{mg}$, respectively. Median FPG changes were $3.0 \mathrm{mg} / \mathrm{dL},-27 \mathrm{mg} / \mathrm{dL},-20 \mathrm{mg} / \mathrm{dL}$, and $-27 \mathrm{mg} /$, respectively. BW showed a significant reduction of approximately $1 \mathrm{~kg}$ in patients treated with EVO $5 \mathrm{mg}(-1.19 \mathrm{~kg} ; 90 \% \mathrm{CI}-1.7 \mathrm{~kg},-0.7 \mathrm{~kg})$, EVO $10 \mathrm{mg}$ $(-1.03 \mathrm{~kg} ; 90 \% \mathrm{CI}-1.8 \mathrm{~kg},-0.3 \mathrm{~kg})$, and SITA $100 \mathrm{mg}$ $(-1.13 \mathrm{~kg} ; 90 \% \mathrm{CI}-1.8 \mathrm{~kg},-0.4 \mathrm{~kg})$, with no significant change in those treated with EVO $2.5 \mathrm{mg}(-0.08 \mathrm{~kg} ; 90 \%$ $\mathrm{CI}-0.8 \mathrm{~kg}, 0.7 \mathrm{~kg}$ ). Similar results were obtained in the PP population.

Mean reductions of HbA1c and FPG levels at the end of the 12-week study treatment adjusted by baseline HbA1c, FPG, BMI, and study site confirmed the significant clinical benefit of all study treatments, showing upper $90 \%$ CIs limits $<-0.5 \%$. These results are illustrated in Figs. 2 and 3 for the ITT population. Similar results were obtained in the PP population. 


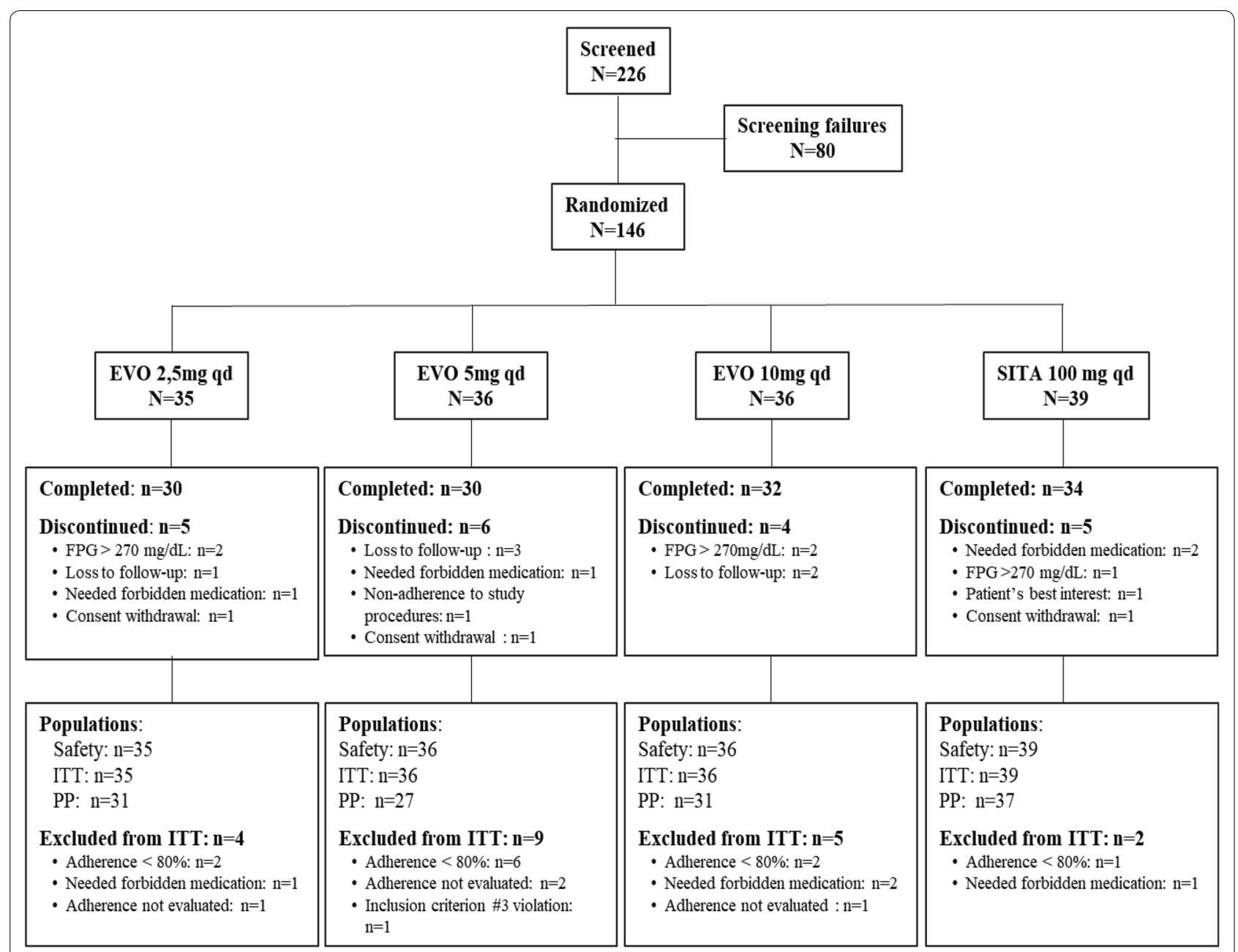

Fig. 1 Disposition of subjects in study groups and populations. EVO evogliptin, FPG fasting plasma glucose, ITT intention-to-treat, PP per protocol, ad once-daily, SITA sitagliptin

For the ITT population, the response rate, defined as the proportion of patients achieving $\mathrm{HbA} 1 \mathrm{c}<7.0 \%$ at the end of the study treatment, was $22.9 \%$ (90\% CI $11.9 \%, 37.5 \%)$ in the group EVO $2.5 \mathrm{mg}, 30.6 \%$ (90\% CI $18.2 \%, 45.5 \%)$ in the group EVO $5 \mathrm{mg}, 27.8 \%(90 \% \mathrm{CI}$ $15.9 \%, 42.6 \%)$ in the group EVO $10 \mathrm{mg}$, and $41.0 \%(90 \%$ CI $27.7 \%, 55.4 \%)$ in the group SITA $100 \mathrm{mg}$. The proportion of patients with $\mathrm{HbA} 1 \mathrm{c}<6.5 \%$ at the end of the study was $14.3 \%$ (90\% CI 5.8\%, 27.7\%), 5.6\% (90\% CI 1.0\%, $16.5 \%$ ), $19.4 \%$ (90\% CI 9.5\%, 33.4\%), and $18.0 \%$ (90\% CI $8.7 \%, 31.1 \%$ ) in subjects treated with EVO $2.5 \mathrm{mg}$, EVO $5 \mathrm{mg}$, EVO $10 \mathrm{mg}$, and SITA $100 \mathrm{mg}$, respectively. Similar results were obtained in the PP population.

Treatment-emergent AEs were reported by 88 (60.3\%) subjects of the safety population $(\mathrm{N}=146)$. The distribution of the reported AEs per study group is summarized in Table 2. AEs reported by $\geq 5 \%$ of the subjects in at least one study group are presented in Table 3.

\section{Discussion}

The primary efficacy analysis showed statistically and clinically significant reductions of HbA1c levels, indicating the clinical benefit of all study treatments, including the "target" group treated with EVO $5 \mathrm{mg}$, in which the mean HbA1c level absolute change was $-1.12 \%(90 \%$ CI $-1.4 \%,-0.8 \%)$. The observed reductions of HbA1c levels observed at the end of the 12-week study treatment compared to baseline values were greater than $1 \%$ in all study groups; these reductions are greater than the reported reductions of HbAlc previously reported for DPP4i in monotherapy (which vary mostly from 0.5 to $0.8 \%$ ) [3, 15-20], possibly due to the high HbA1c levels at baseline. Similarly to the results of a phase II study that aimed to determine the optimal dose of EVO in a Korean population [7], our results failed to show a dose-dependent reduction of HbA1c levels. Likewise, all studied dosages $(2.5,5$ and $10 \mathrm{mg})$ resulted in significant 
Table 1 Demographics and baseline characteristics (ITT population)

\begin{tabular}{|c|c|c|c|c|}
\hline & EVO $2.5 \mathrm{mg}(\mathrm{N}=35)$ & EVO $5 \mathrm{mg}(\mathrm{N}=36)$ & EVO $10 \mathrm{mg}(\mathrm{N}=36)$ & SITA $100 \mathrm{mg}(\mathrm{N}=39)$ \\
\hline \multicolumn{5}{|l|}{ Gender, n (\%) } \\
\hline Female & $16(45.7)$ & $19(52.8)$ & $19(52.8)$ & $18(46.2)$ \\
\hline \multicolumn{5}{|l|}{ Age, years } \\
\hline Mean (SD) & $50.46(9.33)$ & $53.17(11.50)$ & $50.11(9.36)$ & $52.10(10.41)$ \\
\hline \multicolumn{5}{|l|}{$\mathrm{BMI}, \mathrm{kg} / \mathrm{m}^{2}$} \\
\hline Mean (SD) & $29.79(5.04)$ & $30.56(4.18)$ & $29.80(4.71)$ & $30.50(4.76)$ \\
\hline Median & 29.3 & 31.1 & 29.6 & 30.6 \\
\hline Min-max & $20.8-39.9$ & $22.3-39.6$ & $21.4-39.9$ & $20.9-39.7$ \\
\hline \multicolumn{5}{|c|}{ T2DM duration, years ${ }^{\mathrm{a}}$} \\
\hline Mean (SD) & $2.49(4.03)$ & $1.12(2.86)$ & $2.21(4.42)$ & $1.18(2.26)$ \\
\hline Median & 0.6 & 0.0 & 0.1 & 0.2 \\
\hline Min-max & $0.0-18.0$ & $0.0-13.6$ & $0.0-21.0$ & $0.0-11.0$ \\
\hline \multicolumn{5}{|l|}{$\mathrm{HbA} 1 \mathrm{c}, \%$} \\
\hline Mean (SD) & $9.09(0.99)$ & $8.84(0.85)$ & $8.95(0.93)$ & $8.90(0.94)$ \\
\hline Median & 9.2 & 8.8 & 9.0 & 9.0 \\
\hline Min-max & $7.5-10.5$ & $7.5-10.5$ & $7.5-10.5$ & $7.5-10.5$ \\
\hline \multicolumn{5}{|l|}{$\mathrm{FPG}, \mathrm{mg} / \mathrm{dL}$} \\
\hline Mean (SD) & $168.20(48.56)$ & $182.19(42.96)$ & $188.25(50.12)$ & $193.10(56.21)$ \\
\hline Median & 160.0 & 172.0 & 185.0 & 183.0 \\
\hline Min-max & $62.0-293.0$ & $109.0-301.0$ & $122.0-336.0$ & $104.0-342.0$ \\
\hline
\end{tabular}

$B M I$ body mass index, EVO evogliptin, FPG fasting plasma glucose, HbA1c glycated haemoglobin, ITT intention-to-treat, Max maximum, Min minimum, SD standard deviation, SITA sitagliptin, T2DM type 2 diabetes mellitus

a Calculated as the number of years between the diagnosis of T2DM and signature of the informed consent

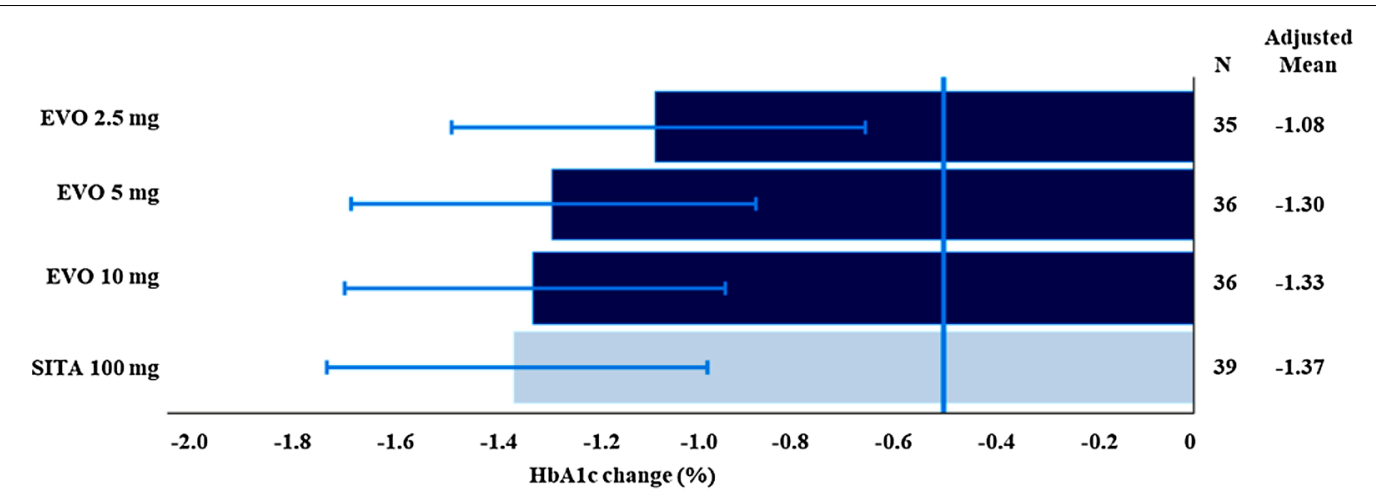

Fig. $2 \mathrm{HbA1C}$ change from baseline to Week 12-adjusted mean and 90\% Cl (ITT population). EVO evogliptin, SITA sitagliptin

and relevant reductions of $\mathrm{HbA1c}$ levels, and the optimal dosage $(5 \mathrm{mg}$ ) was determined through the evaluation of all endpoints in that population of patients.

FPG levels also showed significant reductions in subjects treated with EVO 5 and $10 \mathrm{mg}$, as well as in those treated with SITA $100 \mathrm{mg}$, but not in those treated with EVO $2.5 \mathrm{mg}$. The mean change of FPG associated to the daily monotherapy with SITA $100 \mathrm{mg}[-39.9 \mathrm{mg} /$ $\mathrm{dL}(90 \% \mathrm{CI}-55.1 \mathrm{mg} / \mathrm{dL},-24.7 \mathrm{mg} / \mathrm{dL})]$ was similar to that observed in previous studies [15], confirming the internal validity of our results. The lack of response on FPG levels observed in subjects treated with EVO $2.5 \mathrm{mg}$ may be explained by the small activity of DPP4is on fasting glycaemia, once these agents are known to mainly promote the reduction of postprandial glycaemia [21]. With exception of the patients treated with EVO $2.5 \mathrm{mg}$, the reduction of BW observed is in accordance to the expected for DPP4is [22]. The 


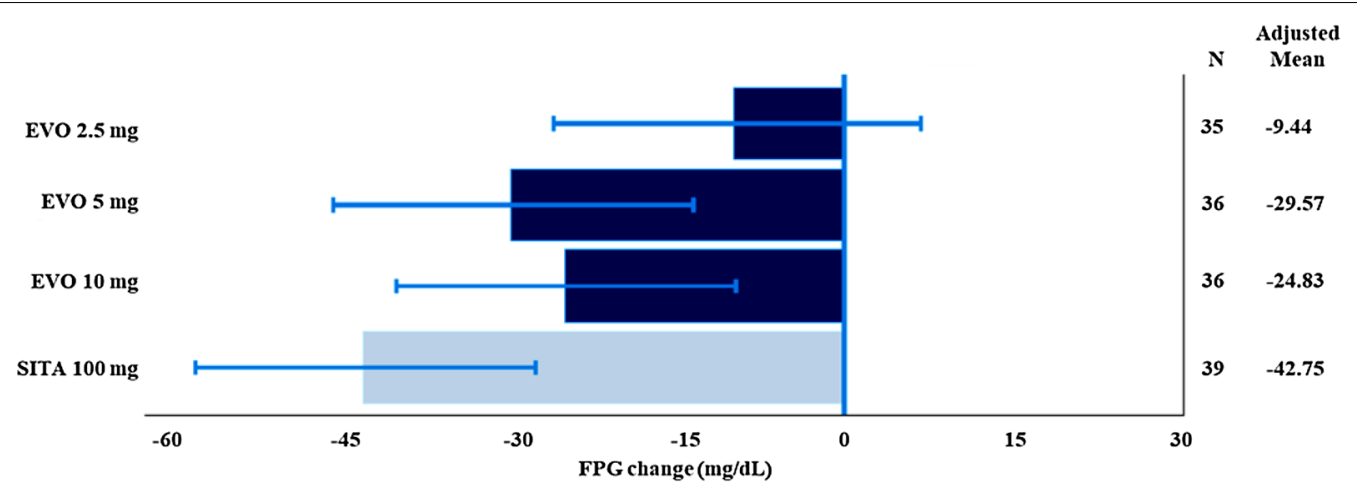

Fig. 3 Fasting plasma glucose change from baseline to Week 12-adjusted mean and 90\% Cl (ITT population). EVO evogliptin, FPG fasting plasma glucose, SITA sitagliptin

Table 2 Adverse events summary (safety population)

EVO $2.5 \mathrm{mg}(\mathrm{N}=35)$ EVO $5 \mathrm{mg}(\mathrm{N}=36)$ EVO $10 \mathrm{mg}(\mathrm{N}=36)$

\section{Subjects with at least $1 \mathrm{AE}$}

$\begin{array}{ll}N(\%) & 23(65.7) \\ 90 \% \mathrm{Cl} & 50.578 .9\end{array}$

Discontinuations due to AEs

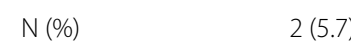

Reported AEs

AEs related ${ }^{\text {a }}$ to study treatment

$\mathrm{N} \quad 0$

$0 \quad 4$
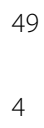

SAES

N

Deaths N

AE adverse event, $90 \% \mathrm{Cl}$ 90\% confidence interval, EVO evogliptin, SAE serious adverse event, SITA sitagliptin

a Possibly or probably related to the study treatment

observed response rates also correspond to those observed with DPP4is in monotherapy [15].

This study was not designed to allow betweengroup statistical comparisons. A group treated with SITA $100 \mathrm{mg}$ was included to enable the validation of our results once the question "Is the studied population responsive to an DPP4i of proved efficacy?" can be answered by the observation of the results of this group. The validation of the efficacy of daily administration of EVO $5 \mathrm{mg}$ in the studied population is supported by the clinical benefit associated to this dose regimen in terms of absolute reduction of HbA1c and FPG levels. The adjusted reductions of HbA1c and FPG levels confirmed these findings.
The sample size was calculated in order to allow the identification of clinically relevant $\mathrm{HbA1c}$ reductions $(\geq 0.5 \%)$ within each treatment group and did not allow between-group comparisons. Despite the fact that between-group comparisons were beyond this bridging study objectives. This might be considered a limitation of our study. Despite the fact that this study was not designed to allow statistical between-groups comparisons, it is noticeable that (a) the reduction of HbA1c showed by patients treated with EVO $5 \mathrm{mg}$ was similar to that observed with EVO $2.5 \mathrm{mg}$, while only the treatment with EVO $5 \mathrm{mg}$ was associated with FPG and BW significant reduction, and (b) compared to the treatment with EVO $10 \mathrm{mg}$, the 12-week daily 
Table 3 Adverse events reported by $\geq 5 \%$ of the patients of any study group (safety population)

\begin{tabular}{|c|c|c|c|c|}
\hline Preferred term (MedDra) & EVO $2.5 \mathrm{mg}(\mathrm{N}=35)$ & EVO $5 \mathrm{mg}(\mathrm{N}=36)$ & EVO $10 \mathrm{mg}(\mathrm{N}=36)$ & $\begin{array}{l}\text { SITA } \\
100 \mathrm{mg} \\
(\mathrm{N}=39)\end{array}$ \\
\hline Headache & $0(0.0)$ & $5(13.9)$ & $1(2.8)$ & $1(2.6)$ \\
\hline GGT elevated & $4(11.4)$ & $0(0.0)$ & $0(0.0)$ & $0(0.0)$ \\
\hline Hypertension & $3(8.6)$ & $2(5.6)$ & $0(0.0)$ & $3(7.7)$ \\
\hline Diarrhea & $3(8.6)$ & $1(2.8)$ & $1(2.8)$ & $2(5.1)$ \\
\hline Flu-like symptoms & $1(2.9)$ & $2(5.6)$ & $3(8.3)$ & $3(7.7)$ \\
\hline Urinary tract infection & $1(2.9)$ & $2(5.6)$ & $3(8.3)$ & $2(5.1)$ \\
\hline T2DM with inadequate control & $2(5.7)$ & $1(2.8)$ & $0(0.0)$ & $1(2.6)$ \\
\hline Dizziness & $0(0.0)$ & $1(2.8)$ & $2(5.6)$ & $1(2.6)$ \\
\hline Eosinophilia & $0(0.0)$ & $2(5.6)$ & $0(0.0)$ & $1(2.6)$ \\
\hline Abdominal pain & $1(2.9)$ & $1(2.8)$ & $2(5.6)$ & $0(0.0)$ \\
\hline Dyslipidemia & $1(2.9)$ & $0(0.0)$ & $2(5.6)$ & $0(0.0)$ \\
\hline Back pain & $0(0.0)$ & $1(2.8)$ & $2(5.6)$ & $0(0.0)$ \\
\hline Upper airway infection & $1(2.9)$ & $2(5.6)$ & $0(0.0)$ & $0(0.0)$ \\
\hline Dyspepsia & $0(0.0)$ & $0(0.0)$ & $2(5.6)$ & $0(0.0)$ \\
\hline Nausea & $1(2.9)$ & $1(2.8)$ & $1(2.8)$ & $2(5.1)$ \\
\hline Hyperglycemia & $1(2.9)$ & $0(0.0)$ & $0(0.0)$ & $2(5.1)$ \\
\hline
\end{tabular}

EVO evogliptin, GGT gamma-glutamyl transferase, T2DM type 2 diabetes mellitus

administration of EVO $5 \mathrm{mg}$ showed similar reductions of HbA1c, FPG and BW, being the lower dosage preferred over the higher. Therefore, our results validate the efficacy of the previously approved dose regimen of EVO (once-daily $5 \mathrm{mg}$ ) to the Brazilian population.

Once-daily treatment with EVO $5 \mathrm{mg}$ was safe and well tolerated. The most frequently reported AEs were similar to those observed with other DPP4is.

\section{Conclusions}

The results of this bridging study validate for the Brazilian population the previously approved dose regimen of EVO (once-daily $5 \mathrm{mg}$ ), hence validate the results of the studies conducted in Korea during its clinical development program for local approval in Brazil.

\begin{abstract}
Abbreviations
AE: adverse event; ALT: alanine aminotransferase; AST: aspartate aminotransferase; BW: body weight; $90 \% \mathrm{Cl}$ : 90\% confidence interval; DPP4i: dipeptidyl peptidase-4 inhibitor; EKG: electrocardiogram; EVO: evogliptin; FPG: fasting plasma glucose; GIP: gastric inhibitory polypeptide; GLP-1: glucagon-like peptide 1; HbA1c: glycated hemoglobin; ITT: intention-to-treat; PP: per protocol; qd: once-daily; SD: standard deviation; SITA: sitagliptin; T2DM: type 2 diabetes mellitus; ULN: upper limit of normal.
\end{abstract}

\section{Acknowledgements}

We thank Maria Cecilia Lorenzi, MD, PhD, for her assistance in the preparation of the manuscript. data.

We thank Rita Antonelli Cardoso DrPH, for the statistical analysis of the

\section{Authors' contributions}

CC made substantial contributions to the conception/design of the work, made substantial contribution to the acquisition of the data, substantively revised the work and approved the submitted version. JSF made substantial contribution to the acquisition of the data, substantively revised the work and approved the submitted version. LATR made substantial contribution to the acquisition of the data, substantively revised the work and approved the submitted version. JLCB made substantial contribution to the acquisition of the data and approved the submitted version. JS made substantial contribution to the acquisition of the data, substantively revised the work and approved the submitted version. PM made substantial contribution to the acquisition of the data, interpreted the patient data and substantively revised the submitted version. TB made substantial contribution to the acquisition of the data, substantively revised the work and approved the submitted version. ARC made substantial contribution to the acquisition of the data, substantively revised the work and approved the submitted version. FE made substantial contribution to the acquisition of the data, substantively revised the work and approved the submitted version. ACF made substantial contribution to the acquisition and interpreted the data, as well as substantively revised the work. All authors read and approved the final manuscript.

\section{Funding}

This study was sponsored by Eurofarma Laboratórios S.A., which provided funding for all study procedures, study treatment, and investigators fees.

\section{Availability of data and materials}

The data that support the findings of this study are available from Eurofarma Laboratórios S.A. (study sponsor), but restrictions apply to the availability of these data, which were used under license for the current study, and so are not publicly available. Data are however available from the corresponding author upon reasonable request and with permission of Eurofarma Laboratórios S.A.

\section{Ethics approval and consent to participate}

The study protocol was approved by the Ethics Committee of each participating study site (listed bellow) and all subjects provided written informed consent for participation in the study. 1. Hospital das Clínicas da Faculdade de 
Medicina da Universidade de São Paulo, Ethics Committee: Hospital das Clínicas da Faculdade de Medicina da USP, 225 Ovídio Pires de Campos st., 05.403-010 São Paulo - SP - Brazil. 2. Hospital Universitário João de Barros Barreto (HUJBB), Ethics Committee: UFPA - Hospital Universitário João de Barros Barreto, 4487 Munducurus st., 66.073-000 - Belem - PA - Brazil. 3. CCBR Brasil - Centro de Pesquisas e Análises Clínicas Ltda., Ethics Committee: PROCEP - Hospital PróCardíaco ESHO Empresa de Serviços Hospitalares, 435 Voluntários da Pátria st., 22.270-005 - Rio de Janeiro - RJ - Brazil. 4. CEM - Clínica de Endocrinologia e Metabologia Ltda., Ethics Committee: UNICEUB - Centro Universitário de Brasília, SEPN 707/907 - Block 6 - 1 rst floor, 70.790-075 - Brasilia - DF - Brazil. 5. Instituto de Pesquisa Clínica Ltda., Ethics Committee: ISBEM - Instituto de Saúde e Bem-Estar da Mulher, 784 Manoel da Nóbrega st., 04.001-002 - São Paulo - SP - Brazil. 6. IMA - Instituto de Pesquisa Clínica e Medicina Avançada Ltda., Ethics Committee: FMABC - Faculdade de Medicina do ABC/Fundação do ABC, 2000 Lauro Gomes Ave., 09.060-870 - Santo André - SP - Brazil. 7. Centro Paulista de Investigação Clínica, Ethics Committee: FMABC - Faculdade de Medicina do ABC/Fundação do ABC, 2000 Lauro Gomes Ave., 09.060870 - Santo André - SP - Brazil. 8. Centro de Pesquisa Clínica em Diabetes da UNIFESP, Ethics Committee: UNIFESP - Hospital São Paulo, 572 Botucatu st. 1 rst floor, 04.023-061 - São Paulo - SP - Brazil. 9. CPCLIN - Centro de Pesquisas Clínicas Ltda., Ethics Committee: Santa Casa de Misericórdia de São Paulo, Santa Isabel, 01.221-010 - São Paulo - SP - Brazil. 10. Centro de Estudos em Diabetes e Hipertensão (CEDH), Ethics Committee: UFC - Universidade Federal do Ceará, 1000 Coronel Nunes st., 60.430-275 - Fortaleza - CE - Brazil.

\section{Consent for publication}

Not applicable.

\section{Competing interests}

ACF, JSF, JLCB, CC - Received financial support for the research and is a speaker for Eurofarma Laboratórios S.A.LATR, JS, PM, TB, ARC, FE-Received financial support for the research.

\section{Author details \\ ${ }^{1}$ Laboratório de Lípides (LIM 10) do Hospital das Clínicas (HCFMUSP) da Faculdade de Medicina da Universidade de São Paulo, São Paulo, Brasil, 155 Dr Enéas de Carvalho de Aguiar ave., São Paulo, SP 05403-000, Brazil. ${ }^{2}$ Hospital Universitário João de Barros Barreto (HUJBB), 4487 Mundurucus st., Belém, PA 66073-005, Brazil. ${ }^{3}$ CCBR Brasil - Centro de Pesquisas e Análises Clínicas Ltda., 33 Mena Barreto st., Rio de Janeiro, RJ 22271-100, Brazil. ${ }^{4}$ CEM - Clínica de Endocrinologia e Metabologia Ltda., SHIS QI 09 Bloco E1 304/305, Brasília, DF 71625-175, Brazil. ${ }^{5}$ Instituto de Pesquisa Clínica Ltda., 503 Marquês de Itú st., São Paulo, SP 01223-001, Brazil. ${ }^{6}$ IMA - Instituto de Pesquisa Clínica e Medicina Avançada Ltda., 55 Américo Jacomino sq., São Paulo, SP 05437-010, Brazil. ${ }^{7}$ Centro Paulista de Investigação Clínica, 342 Moreira e Costa st., São Paulo, SP 04266-010, Brazil. ${ }^{8}$ Centro de Pesquisa Clínica em Diabetes da UNIFESP, 639 Estado de Israel st., São Paulo, SP 04022-001, Brazil. ${ }^{9}$ CPCLIN - Centro de Pesquisas Clínicas Ltda., Avenida Angélica 2162, São Paulo, SP 01228-200, Brazil. ${ }^{10}$ Centro de Estudos em Diabetes e Hipertensão (CEDH), 2434 Dr Jose Lourenço st., Fortaleza, CE 60115-282, Brazil.}

Received: 12 September 2019 Accepted: 11 December 2019 Published online: 19 December 2019

\section{References}

1. Deacon CF. What do we know about the secretion and degradation of incretin hormones? Regul Pept. 2005;128(2):117-24.

2. Drucker DJ, Nauck MA. The incretin system: glucagon-like peptide-1 receptor agonists and dipeptidyl peptidase-4 inhibitors in type 2 diabetes. Lancet. 2006;368(9548):1696-705.

3. Zhong J, Gong Q, Goud A, Srinivasamaharaj S, Rajagopalan S. Recent advances in dipeptidyl-peptidase-4 inhibition therapy: lessons from the bench and clinical trials. J Diabetes Res. 2015. https://doi. org/10.1155/2015/606031.

4. Kim MK, Chae YN, Kim HD, Yang EK, Cho EJ, Choi SH, et al. DA-1229, a novel and potent DPP4 inhibitor, improves insulin resistance and delays the onset of diabetes. Life Sci. 2012;90(1-2):21-9.

5. Kim TE, Lim KS, Park MK, Yoon SH, Cho JY, Shin SG, et al. Evaluation of the pharmacokinet-ics, food effect, pharmacodynamics, and tolerability of
DA-1229, a dipeptidyl peptidase IV inhibitor, in healthy volunteers: first-inhuman study. Clin Ther. 2012;34(9):1986-98.

6. Gu N, Park MK, Kim TE, Bahng MY, Lim KS, Cho SH, et al. Multiple-dose pharmacokinetics and pharmacodynamics of evogliptin (DA-1229), a novel dipeptidyl peptidase IV inhibitor, in healthy volunteers. Drug Des Devel Ther. 2014;8:1709-21.

7. Jung $\mathrm{CH}$, Park CY, Ahn KJ, Kim NH, Jang HC, Lee MK, et al. A randomized, double-blind, placebo-controlled, phase II clinical trial to investigate the efficacy and safety of oral DA-1229 in patients with type 2 diabetes mellitus who have inadequate glycaemic control with diet and exercise. Diabetes Metab Res Rev. 2015;31(3):295-306.

8. Park J, Park SW, Yoon KH, Kim SR, Ahn KJ, Lee JH, et al. Efficacy and safety of evogliptin monotherapy in patients with type 2 diabetes and moderately elevated glycated haemoglobin levels after diet and exercise. Diabetes Obes Metab. 2017;19(12):1681-7.

9. Hong SM, Park CY, Hwang DM, Han KA, Lee CB, Chung CH, et al. Efficacy and safety of adding evogliptin versus sitagliptin for metformin-treated patients with type 2 diabetes: a 24-week randomized, controlled trial with open label extension. Diabetes Obes Metab. 2017;19(5):654-63.

10. Louisa M, Takeuchi M, Takeuchi M, Nafrialdi N, Setiabudy R. Incretin-based therapies for type 2 diabetes mellitus in Asian patients: analysis of clinical trials. Med J Indones. 2010;19(3):205-12.

11. Kim YG, Hahn S, Oh TJ, Kwak SH, Park KS, Cho YM. Differences in the glucose-lowering efficacy of dipeptidyl peptidase-4 inhibitors between Asians and non-Asians: a systematic review and meta-analysis. Diabetologia. 2013;56(4):696-708.

12. Foley JE, Bhosekar V, Kawamori R. Does the treatment of type 2 diabetes mellitus with the DPP-4 inhibitor vildagliptin reduce $\mathrm{HbA} 1 \mathrm{c}$ to a greater extent in Japanese patients than in Caucasian patients? Vasc Health Risk Manag. 2016;12:9-12.

13. Nonaka K, Kakikawa T, Sato A, Okuyama K, Fujimoto G, Kato N, et al. Efficacy and safety of sitagliptin monotherapy in Japanese patients with type 2 diabetes. Diabetes Res Clin Pract. 2008;79(2):291-8.

14. International Conference on Harmonisation of Technical Requirements for Registration of Pharmaceuticals for Human Use-ICH Harmonised Tripartite Guideline. Ethnic Factors in the Acceptability of Foreign Clinical Data E5 (R1). https://www.ich.org/products/guidelines/efficacy/efficacy-single/article/ ethnic-factors-in-the-acceptability-of-foreign-clinical-data.html. Accessed 22 July 2019.

15. Aschner P, Kipnes MS, Lunceford JK, Sanchez M, Mickel C, Williams-Herman DE, et al. Effect of the dipeptidyl peptidase-4 inhibitor sitagliptin as monotherapy on glycemic control in patients with type 2 diabetes. Diabetes Care. 2006;29(12):2632-7.

16. Pi-Sunver FX, Schweizer A, Mills D, Dejager S. Efficacy and tolerability of vildagliptin monotherapy in drug-naïve patients with type 2 diabetes. Diabetes Res Clin Pract. 2007;76(1):132-8.

17. Del Prato S, Barnett AH, Huisman H, Neubacher D, Woerle HJ, Dugi KA. Effect of linagliptin monotherapy on glycaemic control and markers of $\beta$-cell function in patients with inadequately controlled type 2 diabetes: a randomized controlled trial. Diabetes Obes Metab. 2011;13(3):258-67.

18. Pan CY, Yang W, Tou C, Gause-Nilsson I, Zhao J. Efficacy and safety of saxagliptin in drug-naïve Asian patients with type 2 diabetes mellitus: a randomized controlled trial. Diabetes Metab Res Rev. 2012;28(3):268-75.

19. Yang SJ, Min KW, Gupta SK, Park JY, Shivane VK, Pitale SU, et al. A multicenter, multinational, randomized, placebo-controlled, double-blind, phase 3 trial to evaluate the efficacy and safety of gemigliptin (LC15-0444) in patients with type 2 diabetes. Diabetes Obes Metab. 2013;15(5):410-6.

20. Yavropoulou MP, Pikilidou M, Kotsa K, Michopoulos A, Papakonstantinou E, Yovos JG. Efficacy and tolerability of fildagliptin as first line treatment in patients with diabetes type 2 in an outpatient setting. J Diabetes Metab Disord. 2015;14:68.

21. Rhee NA, Østoft SH, Holst JJ, et al. The impact of dipeptidyl peptidase 4 inhibition on incretin effect, glucose tolerance, and gastrointestinal-mediated glucose disposal in healthy subjects. Eur J Endocrinol. 2014;171(3):353-62.

22. Neumiller JJ, Wood L, Campbell RK. Dipeptidyl peptidase-4 inhibitors for the treatment of type 2 diabetes mellitus. Pharmacotherapy. 2010;30(5):463-84.

\section{Publisher's Note}

Springer Nature remains neutral with regard to jurisdictional claims in published maps and institutional affiliations. 